\title{
IMPLEMENTASI METODE SIMPLE ADDITIVE WEIGHTING SEBAGAI SISTEM REKOMENDASI PEMILIHAN TANAMAN PANGAN YANG LAYAK DI KABUPATEN MALANG
}

\author{
Ibnu Arifin', Moh. Ahsan², Alexius Endy Budianto ${ }^{3}$ \\ Program Studi Teknik Informatika, Universitas Kanjuruhan Malang 1,2,3 \\ ibnuadiarifin@gmail.com, ahsan@unikama.ac.id,endybudianto@unikama.ac.id
}

\begin{abstract}
Abstrak. Keberhasilan bisnis petani di sektor pertanian tidak semata-mata karena keberuntungan semata, tetapi ada beberapa faktor yang mempengaruhinya. Beberapa faktor yang mempengaruhinya, seperti tanah pertanian (tanah), tenaga kerja, modal, pupuk, pestisida, benih, teknologi, dan manajemen. Dari beberapa faktor ini, ada juga faktor alam seperti sinar matahari, curah hujan, angin, lingkungan yang juga mempengaruhi proses pertanian. Berdasarkan hasil pengamatan, waktu lahan yang dihadapi petani adalah kurangnya pengetahuan untuk menentukan jenis tanaman pangan yang tepat yang cocok untuk ditanam di daerah beriklim tertentu berdasarkan parameter suhu, tekanan udara, kecepatan angin, kelembaban udara, curah hujan, dan ketinggian lokasi penanaman. Sehubungan dengan masalah-masalah ini, pemerintah Kabupaten Malang dengan cepat meningkatkan kesejahteraan petani dengan program tanaman pangan yang sesuai dengan kondisi lahan yang ada berdasarkan parameterparameter ini. Sistem rekomendasi metode SAW adalah sistem informasi interaktif untuk membantu pengambilan keputusan dalam situasi semi-terstruktur dan tidak terstruktur, di mana tidak ada yang tahu pasti bagaimana keputusan itu diambil. Berdasarkan hasil implementasi, dengan sistem rekomendasi, dapat ditemukan bahwa itu dapat membantu petani sebagai pengambil keputusan untuk memilih tanaman pangan yang cocok ditanam oleh petani di Kabupaten Malang.
\end{abstract}

Kata Kunci: Sistem Pendukung Keputusan; Metode Simply Addative Weighting; Petani; Kabupaten Malang.

\section{PENDAHULUAN}

Pertanian merupakan mata pencaharian yang banyak di lakukan oleh masyarakat Indonesia. Kabupaten Malang dengan potensi lahan yang luas dengan keanekaragaman hayati yang merupakan modal utama dalam pengembangan sektor tanaman pangan dan hortikultura. Keanekaragaman lahan tersebut meliputi lahan irigasi, lebak, tadah hujan dan lahan lembab. Kebijakan pembangunan tanaman pangan dan hortikultura di Kabupaten Malang di lakukan melalui program-program yang tepat, jelas dan terarah sesuai dengan potensi yang ada. Berdasarkan hasil observasi, permasalahan yang dihadapi oleh para petani yaitu kurangnya pengetahuan untuk menentukan jenis tanaman pangan yang tepat dan cocok untuk ditanam pada iklim tertentu berdasarkan parameter suhu, tekanan udara, kecepatan angin, kelembaban udara, curah hujan, dan ketinggian lokasi tanam. Sehubungan dengan permasalahan tersebut, pemerintah Kabupaten Malang sigap untuk memajukan kesejahteraan petani dengan program tanaman pangan yang tepatsesuai dengan keadaan lahan yang ada berdasarkan parameter tersebut.

\section{METODE PENELITIAN}

Metode penelitian yang digunakan dalam penelitian ini adalah penelitian dan pengembangan (research and development). Pembangunan Sistem Rekomendasi Pemilihan Tanaman Pangan Yang Layak di Kabupaten Malang Metode Simple Additive Weighting menggunakan model pengembangan perangkat lunak waterfall. Terdapat Empat langkah dalam model pengembangan perangkat lunak waterfall yang di gambarkan seperti gambar dibawah ini 


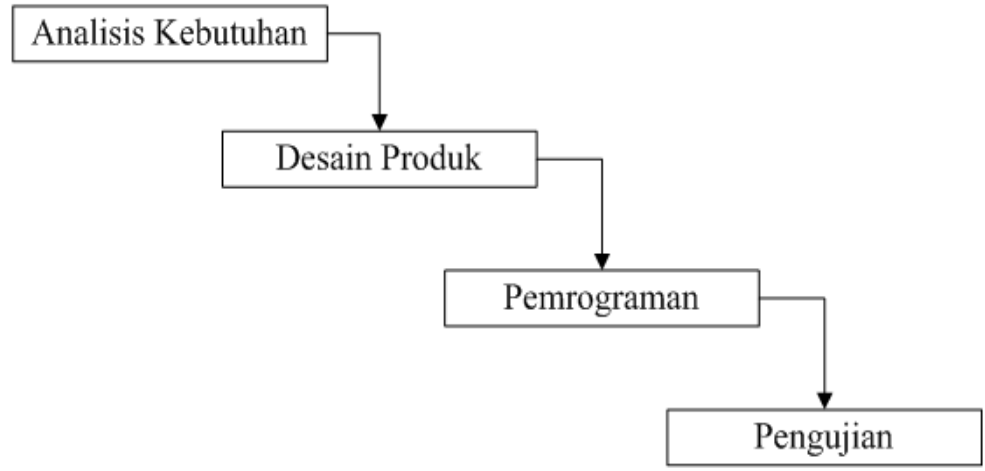

Gambar 1. Alur Metode Penelitian

\section{Analisis Kebutuhan}

Pada proses ini, di lakukan penganalisaan dan pengumpulan kebutuhan sistem yang meliputi observasi dan wawancara untuk mendapat kan data dan fakta permasalahan, penyusunan table kebutuhan fungsional dan non fungsional berdasarkan hasil observasi dan wawancara kepada tenaga staff Pemerintah Kabupaten Malang. Penyusunan aktor yang terlibat di dalam sistem, penyusunan kebutuhan hardware dan software.

\section{Desain Produk}

Pada tahapan desain produk, peneliti melanjutkan dari tahapan analisa kebutuhan. Pada proses ini di lakukan penerjemahan syarat kebutuhan sebuah perancangan perangkat lunak yang dapat di perkirakan sebelum dibuat nya proses pengkodean.

\section{Pemrograman}

Pemrograman merupakan proses menterjemah kan perancangan desain kebentuk yang dapat di mengerti oleh mesin, dengan menggunakan bahasa pemrograman. Pengkodean pada tahapini menggunakan bahasa pemrograman PHP (Hypertext Preprocessor).

\section{Pengujian}

Setelah proses pemrograman selesai, di lanjutkan dengan proses pengujian pada program perangkat lunak, baik pengujian logika internal, maupun pengujian eksternal fungsional untuk memeriksa segala kemungkinan terjadi nya kesalahan dan memeriksa apakah hasil dari pengembangan tersebut sesuai dengan hasil yang di inginkan.

\section{HASIL DAN PEMBAHASAN}

Pembahasan Produk menggunakan metode SAW ialah sebagai berikut.

1. Menentukan alternatif (kandidat), yaitu Ai.

\begin{tabular}{ll}
\multicolumn{2}{c}{ Tabel 1. Alternatif } \\
\hline KD & \multicolumn{1}{c}{ Alternatif } \\
\hline R1 & Jagung \\
\hline R2 & Wortel \\
\hline R3 & Kedelai \\
\hline R4 & Kacang Tanah \\
\hline R5 & Ubi Jalar \\
\hline R6 & Ubi Kayu \\
\hline R7 & Kacang Hijau \\
\hline R8 & Kentang \\
\hline R9 & Singkong \\
\hline R10 & Cabe \\
\hline
\end{tabular}

2. Menentukan kriteria yang akan di jadikan acuan dalam pengambilan keputusan, yaitu $\mathrm{Cj}$. 
Tabel 2. Kriteria

\begin{tabular}{ll}
\hline Kd & Kriteria \\
\hline C1 & Suhu \\
\hline C2 & Tekanan Udara \\
\hline C3 & Kelembapan Udara \\
\hline C4 & Curah Hujan \\
\hline C5 & Ketinggian Lokasi \\
\hline
\end{tabular}

3. Memberikan nilai rating kecocokan setiap alternatif pada setiap kriteria.

Tabel 3. Alternatif dari setiap kreteria

\begin{tabular}{llccccc}
\hline KD & Alternatif & C1 & C2 & C3 & C4 & C5 \\
\hline R1 & Jagung & 3 & 4 & 4 & 4 & 3 \\
\hline R2 & Wortel & 4 & 2 & 3 & 2 & 3 \\
\hline R3 & Kedelai & 3 & 4 & 4 & 2 & 3 \\
\hline R4 & Kacang Tanah & 4 & 3 & 4 & 2 & 5 \\
\hline R5 & UbiJalar & 3 & 4 & 4 & 5 & 3 \\
\hline R6 & UbiKayu & 4 & 2 & 3 & 4 & 3 \\
\hline R7 & KacangHijau & 1 & 3 & 2 & 5 & 3 \\
\hline R8 & Kentang & 1 & 3 & 2 & 5 & 3 \\
\hline R9 & Singkong & 2 & 2 & 4 & 2 & 3 \\
\hline R10 & Cabe & 4 & 2 & 3 & 5 & 4 \\
\hline & & & & & &
\end{tabular}

4. Menentukan bobot preferensi atau tingkat kepentingan (W) setiap kriteria.

Tabel 4. Bobot Preferensi

\begin{tabular}{lll}
\hline Kd & Kriteria & Bobot \\
\hline C1 & Suhu & 4 \\
\hline C2 & Tekanan Udara & 3 \\
\hline C3 & Kelembapan Udara & 3 \\
\hline C4 & Curah Hujan & 2 \\
\hline C5 & Ketinggian Lokasi & 2 \\
\hline
\end{tabular}

5. Membuat tabel rating kecocokan dari setiap alternatif pada setiap kriteria seperti yang di jelaskan di point 4.1.3.1 di atas

6. Membuat matrik keputusan $X$ yang di bentuk dari tabel rating kecocokan dari setiap alternatif pada setiap kriteria. Nilai $\mathrm{x}$ setiap alternatif (Ai) pada setiap kriteria $(\mathrm{Cj})$ yang sudah di tentukan, dimana, $i=1,2, \ldots \mathrm{m}$ dan $\mathrm{j}=1,2, \ldots \mathrm{n}$.

Tabel 5. Matrik Keputusan

\begin{tabular}{llccccc}
\hline KD & Alternatif & C1 & C2 & C3 & C4 & C5 \\
\hline R1 & Jagung & 3 & 4 & 4 & 4 & 3 \\
\hline R2 & Wortel & 4 & 2 & 3 & 2 & 3 \\
\hline R3 & Kedelai & 3 & 4 & 4 & 2 & 3 \\
\hline R4 & Kacang Tanah & 4 & 3 & 4 & 2 & 5 \\
\hline R5 & Ubi Jalar & 3 & 4 & 4 & 5 & 3 \\
\hline R6 & Ubi Kayu & 4 & 2 & 3 & 4 & 3 \\
\hline R7 & Kacang Hijau & 1 & 3 & 2 & 5 & 3 \\
\hline R8 & Kentang & 1 & 3 & 2 & 5 & 3 \\
\hline R9 & Singkong & 2 & 2 & 4 & 2 & 3 \\
\hline R10 & Cabe & 4 & 2 & 3 & 5 & 4 \\
\hline
\end{tabular}


7. Melakukan normalisasi matrik keputusan $X$ dengan carameng hitung nilai rating kinerja ternomalisasi (rij) dari alternatif Ai pada criteria $\mathrm{Cj}$.

Keterangan :

- benefit, setiap elemen matriks di bagi dengan max dari baris matriks

- cost, min dari kolom matriks di bagi dengan setiap elemen matriks.

Misal untuk kriteria $\mathrm{C} 1$ pada setiap alternatif, karena benefit, maka kita cari max $(3,4,3,4,3,4,1,1,2,4)=4$.Sehingga untuk:

\section{Tabel 6. Normalisai Matrik}

\begin{tabular}{lll}
\hline Kode & \multicolumn{1}{c}{ Alternatif } & Hitung (Benefit) \\
\hline R1 & Jagung & $3 / 4=0,75$ \\
\hline R2 & Wortel & $4 / 4=1$ \\
\hline R3 & Kedelai & $3 / 4=0,75$ \\
\hline R4 & Kacang Tanah & $4 / 4=1$ \\
\hline R5 & Ubi Jalar & $3 / 4=0,75$ \\
\hline R6 & Ubi Kayu & $4 / 4=1$ \\
\hline R7 & Kacang Hijau & $1 / 4=0,25$ \\
\hline R8 & Kentang & $1 / 4=0,25$ \\
\hline R9 & Singkong & $2 / 4=0,5$ \\
\hline R10 & Cabe & $4 / 4=1$ \\
\hline
\end{tabular}

Sedangkan untuk criteria $\mathrm{C} 2$ pada setiap alternatif, karena benefit, maka kitacari $\max (4,2,4,3,4,2,3,3,2,2)=4$.Sehingga untuk:

Tabel 7. Alternatif Benefit

\begin{tabular}{lll}
\hline Kode & \multicolumn{1}{c}{ Alternatif } & Hitung (Benefit) \\
\hline R1 & Jagung & $4 / 4=1$ \\
\hline R2 & Wortel & $2 / 4=0,5$ \\
\hline R3 & Kedelai & $4 / 4=1$ \\
\hline R4 & Kacang Tanah & $3 / 4=0,75$ \\
\hline R5 & Ubi Jalar & $4 / 4=1$ \\
\hline R6 & Ubi Kayu & $2 / 4=0,5$ \\
\hline R7 & Kacang Hijau & $3 / 4=0,75$ \\
\hline R8 & Kentang & $3 / 4=0,75$ \\
\hline R9 & Singkong & $2 / 4=0,5$ \\
\hline R10 & Cabe & $2 / 4=0,5$ \\
\hline
\end{tabular}

Untuk kriteria C3 pada setiap alternatif, karena benefit, maka kitacari max (4, 3, 4, 4, 4, 3, 2, 2, 4, 3) $=4$.Sehingga untuk:

Tabel 8. Alternatif Benefit

\begin{tabular}{lll}
\hline \multicolumn{1}{c}{ Kode } & \multicolumn{1}{c}{ Alternatif } & Hitung (Benefit) \\
\hline R1 & Jagung & $4 / 4=1$ \\
\hline R2 & Wortel & $3 / 4=0,75$ \\
\hline R3 & Kedelai & $4 / 4=1$ \\
\hline R4 & Kacang Tanah & $4 / 4=1$ \\
\hline R5 & Ubi Jalar & $4 / 4=1$ \\
\hline R6 & Ubi Kayu & $3 / 4=0,75$ \\
\hline R7 & Kacang Hijau & $2 / 4=0,5$ \\
\hline R8 & Kentang & $2 / 4=0,5$ \\
\hline
\end{tabular}




\begin{tabular}{lll}
\hline R9 & Singkong & $4 / 4=1$ \\
\hline R10 & Cabe & $3 / 4=0,75$ \\
\hline
\end{tabular}

Untuk kriteria $\mathrm{C} 4$ pada setiap alternatif, karena benefit, maka kita cari max $(4,2,2$, $2,5,4,5,5,2,5)=5$.Sehingga untuk:

Tabel 9. Alternatif Benefit

\begin{tabular}{lll}
\hline \multicolumn{1}{c}{ Kode } & \multicolumn{1}{c}{ Alternatif } & Hitung (Benefit) \\
\hline R1 & Jagung & $4 / 5=0,8$ \\
\hline R2 & Wortel & $2 / 5=0,4$ \\
\hline R3 & Kedelai & $2 / 5=0,4$ \\
\hline R4 & Kacang Tanah & $2 / 5=0,4$ \\
\hline R5 & Ubi Jalar & $5 / 5=1$ \\
\hline R6 & Ubi Kayu & $4 / 5=0,8$ \\
\hline R7 & Kacang Hijau & $5 / 5=1$ \\
\hline R8 & Kentang & $5 / 5=1$ \\
\hline R9 & Singkong & $2 / 5=0,4$ \\
\hline R10 & Cabe & $5 / 5=1$ \\
\hline
\end{tabular}

Untuk kriteria C5 pada setiap alternatif, karena benefit, maka kitacari max (3, 3, 3, $5,3,3,3,3,3,4)=5$.Sehingga untuk:

Tabel 10. Alternatif Benefit

\begin{tabular}{lll}
\hline \multicolumn{1}{c}{ Kode } & \multicolumn{1}{c}{ Alternatif } & Hitung (Benefit) \\
\hline R1 & Jagung & $3 / 5=0,6$ \\
\hline R2 & Wortel & $3 / 5=0,6$ \\
\hline R3 & Kedelai & $3 / 5=0,6$ \\
\hline R4 & Kacang Tanah & $5 / 5=1$ \\
\hline R5 & Ubi Jalar & $3 / 5=0,6$ \\
\hline R6 & Ubi Kayu & $3 / 5=0,6$ \\
\hline R7 & Kacang Hijau & $3 / 5=0,6$ \\
\hline R8 & Kentang & $3 / 5=0,6$ \\
\hline R9 & Singkong & $3 / 5=0,6$ \\
\hline R10 & Cabe & $4 / 8=0,8$ \\
\hline
\end{tabular}

8. Hasil dari nilai rating kinerja ternomalisasi (rij) membentuk matrik ternormalisasi (R).

Tabel 11. Nilai Rating Ternormalisasi

\begin{tabular}{|c|c|c|c|c|c|c|}
\hline \\
\hline Kode & Alternative & $\mathrm{C} 1$ & $\mathrm{C} 2$ & $\mathrm{C} 3$ & $\mathrm{C} 4$ & $\mathrm{C} 5$ \\
\hline R1 & Jagung & 0,75 & 1 & 1 & 0,8 & 0,6 \\
\hline R2 & Wortel & 1 & 0,5 & 0,75 & 0,4 & 0,6 \\
\hline R3 & Kedelai & 0,75 & 1 & 1 & 0,4 & 0,6 \\
\hline $\mathrm{R} 4$ & Kacang Tanah & 1 & 0,75 & 1 & 0,4 & 1 \\
\hline $\mathrm{R} 5$ & Ubi Jalar & 0,75 & 1 & 1 & 1 & 0,6 \\
\hline R6 & Ubi Kayu & 1 & 0,5 & 0,75 & 0,8 & 0,6 \\
\hline R7 & Kacang Hijau & 0,25 & 0,75 & 0,5 & 1 & 0,6 \\
\hline $\mathrm{R} 8$ & Kentang & 0,25 & 0,75 & 0,5 & 1 & 0,6 \\
\hline R9 & Singkong & 0,5 & 0,5 & 1 & 0,4 & 0,6 \\
\hline R10 & Cabe & 1 & 0,5 & 0,75 & 1 & 0,8 \\
\hline
\end{tabular}


9. Hasil akhir nilai preferensi (Vi) di peroleh dari penjumlahan dari perkalian elemen baris matrik ternormalisasi $(\mathrm{R})$ dengan bobot preferensi (W) yang bersesuaian elemen kolom matrik (W).

$$
\begin{aligned}
& \mathrm{R} 1=(0.75 * 4)+(1 * 3)+(1 * 3)+(0.8 * 2)+(0.6 * 2)=\mathbf{1 1 . 8} \\
& \mathrm{R} 2=(1 * 4)+(0.5 * 3)+(0.75 * 3)+(0.4 * 2)+(0.6 * 2)=\mathbf{9 . 7 5} \\
& \mathrm{R} 3=(0.75 * 4)+(1 * 3)+(1 * 3)+(0.4 * 2)+(0.6 * 2)=\mathbf{1 1} \\
& \mathrm{R} 4=(1 * 4)+(0.75 * 3)+(1 * 3)+(0.4 * 2)+(1 * 2)=\mathbf{1 2 . 0 5} \\
& \mathrm{R} 5=(0.75 * 4)+(1 * 3)+(1 * 3)+(1 * 2)+(0.6 * 2)=\mathbf{1 2 . 2} \\
& \mathrm{R} 6=(1 * 4)+(0.5 * 3)+(0.75 * 3)+(0.8 * 2)+(0.6 * 2)=\mathbf{1 0 . 5 5} \\
& \mathrm{R} 7=(0.25 * 4)+(0.75 * 3)+(0.5 * 3)+(1 * 2)+(0.6 * 2)=\mathbf{7 . 9 5} \\
& \mathrm{R} 8=(0.25 * 4)+(0.75 * 3)+(0.5 * 3)+(1 * 2)+(0.6 * 2)=\mathbf{7 . 9 5} \\
& \mathrm{R} 9=(0.5 * 4)+(0.5 * 3)+(1 * 3)+(0.4 * 2)+(0.6 * 2)=\mathbf{8 . 5} \\
& \mathrm{R} 10=(1 * 4)+(0.5 * 3)+(0.75 * 3)+(1 * 2)+(0.8 * 2)=\mathbf{1 1 . 3 5}
\end{aligned}
$$

10. Perangkingan

Perangkingan di lakukan dengancara mengalikan nilai SAW dengan nilai Indikasi dan hasil akhir dari nilai akan di rangking sesuai urutan hasiil yang mempunyai nilai paling besar sampai yang terkecil.

Tabel 12. Perangkingan

\begin{tabular}{llcccccc}
\hline Kode & \multicolumn{1}{c}{ Alternative } & C1 & C2 & C3 & C4 & C5 & Hasil \\
\hline R1 & Jagung & 0,75 & 1 & 1 & 0,8 & 0,6 & 11,8 \\
\hline R2 & Wortel & 1 & 0,5 & 0,75 & 0,4 & 0,6 & 9,75 \\
\hline R3 & Kedelai & 0,75 & 1 & 1 & 0,4 & 0,6 & 11 \\
\hline R4 & Kacang Tanah & 1 & 0,75 & 1 & 0,4 & 1 & 12,05 \\
\hline R5 & Ubi Jalar & 0,75 & 1 & 1 & 1 & 0,6 & 12,2 \\
\hline R6 & Ubi Kayu & 1 & 0,5 & 0,75 & 0,8 & 0,6 & 10,55 \\
\hline R7 & Kacang Hijau & 0,25 & 0,75 & 0,5 & 1 & 0,6 & 7,95 \\
\hline R8 & Kentang & 0,25 & 0,75 & 0,5 & 1 & 0,6 & 7,95 \\
\hline R9 & Singkong & 0,5 & 0,5 & 1 & 0,4 & 0,6 & 8,5 \\
\hline R10 & Cabe & 1 & 0,5 & 0,75 & 1 & 0,8 & 11,35 \\
\hline
\end{tabular}

Hasil perhitungan nilai Vi yang lebih besar mengindikasi kan bahwa alternatif Ai merupakan alternative terbaik yang pada perhitungan diatas alternative terbaik ialah $\mathbf{R 5}$ yaitu UbiJalar.

Sistem Rekomendasi Tanaman Pangan di bagi menjadi dua user yaitu admin dan user. Dalam menu user hanya terdapat tigafitur 1) Login User, 2) Prediksi Berdasarkan Kriteria, dan 3) Hasil Rekomendasi Tanaman Pangan. Sedangkan dalam menu admin terdapat tujuh fitur yaitu 1) Login User, 2) Mastering Data Kriteria, 3) Mastering Data Tanaman Pangan, 4) Mastering Nilai, 5) Penilaian / Data Proses Hitung, 6) Laporan Hasil Rekomendasi, 7) Cetak Laporan Rekomendasi.

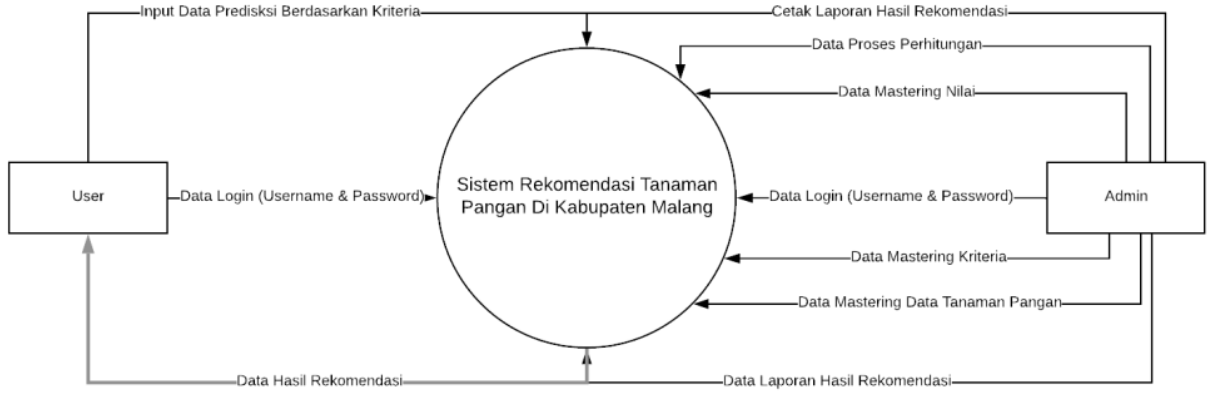

Gambar 2. Entity Sisyem 


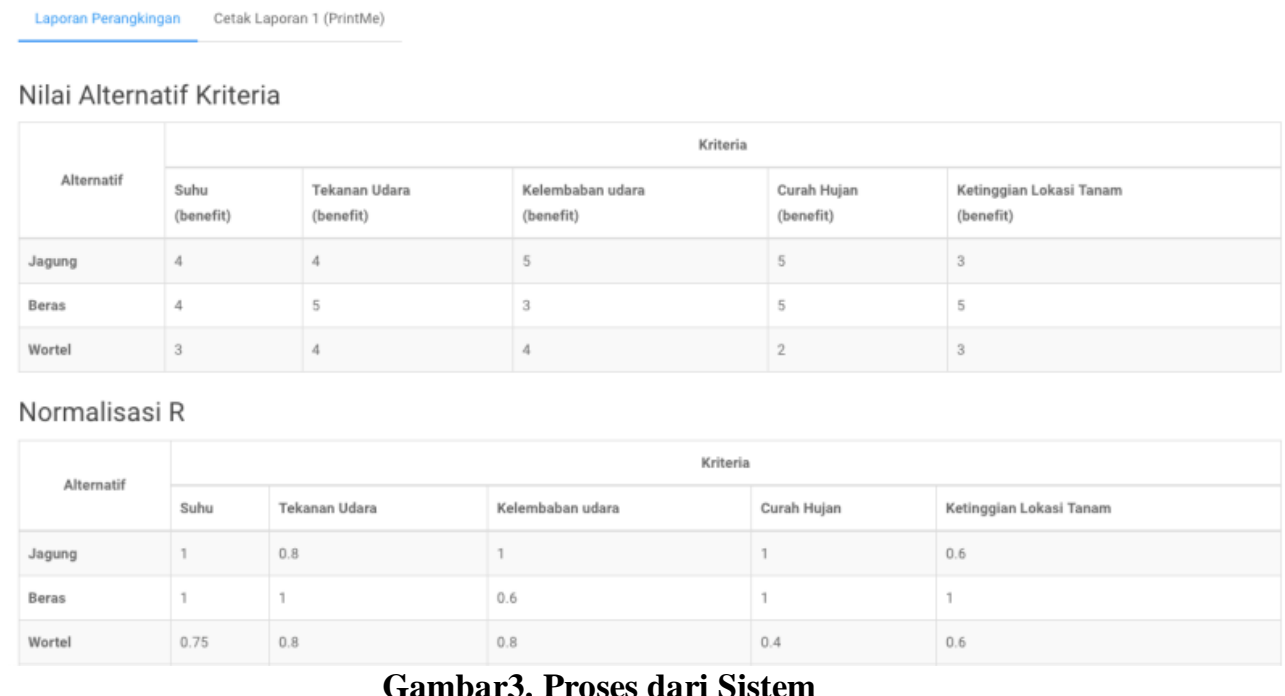

Setelah di lakukan implementasi dan mencoba sistem yang di buat.

Tabel 13. Hasil Uji

\begin{tabular}{|c|c|c|c|c|c|c|c|c|}
\hline \multirow[b]{2}{*}{ No } & \multicolumn{5}{|c|}{ Kriteria } & \multicolumn{2}{|c|}{ Alternatif } & \multirow[t]{2}{*}{ Ket. } \\
\hline & Suhu & $\begin{array}{l}\text { Tekanan } \\
\text { udara }\end{array}$ & $\begin{array}{l}\text { Kelembapan } \\
\text { udara }\end{array}$ & $\begin{array}{l}\text { Curah } \\
\text { hujan }\end{array}$ & $\begin{array}{l}\text { Ketingian lokasi } \\
\text { tanam }\end{array}$ & Expert & SAW & \\
\hline 1 & Cukup & Cukup & $\begin{array}{c}\text { Sangat } \\
\text { baik }\end{array}$ & $\begin{array}{c}\begin{array}{c}\text { Sangat } \\
\text { baik }\end{array} \\
\end{array}$ & Cukup baik & $\begin{array}{l}\text { Jagung,ubi jalar, } \\
\text { kedelai }\end{array}$ & $\begin{array}{l}\text { Wortel, jagung, } \\
\text { dan ubi jalar. }\end{array}$ & Sesuai \\
\hline 2 & Cukup & Sangat baik & Tidak baik & $\begin{array}{c}\text { Sangat } \\
\text { baik }\end{array}$ & Cukup baik & $\begin{array}{l}\text { Ubijalar, wortel, } \\
\text { jagung }\end{array}$ & $\begin{array}{l}\text { Wortel, jagung, } \\
\text { dan ubi jalar. }\end{array}$ & Sesuai \\
\hline 3 & $\begin{array}{c}\text { Tidak } \\
\text { baik }\end{array}$ & Cukup & Sangat baik & Sangat baik & $\begin{array}{l}\text { Sangat } \\
\text { baik }\end{array}$ & $\begin{array}{l}\text { Wortel, ubi jalar, } \\
\text { kacang tanah }\end{array}$ & $\begin{array}{l}\text {, Kacang tanah,ubi } \\
\text { jalar, dan wortel }\end{array}$ & sesuai \\
\hline 4 & $\begin{array}{c}\text { Sangat } \\
\text { baik }\end{array}$ & Cukup & Cukup baik & Sangat baik & Cukup baik & $\begin{array}{l}\text { Cabe, ubi jalar, } \\
\text { jagung }\end{array}$ & $\begin{array}{l}\text { Ubi jalar, cabe, } \\
\text { dan jagung }\end{array}$ & sesuai \\
\hline 5 & $\begin{array}{l}\text { Tidak } \\
\text { baik }\end{array}$ & baik & Cukup & Cukup baik & Cukup baik & $\begin{array}{l}\text { Kacang tanah, } \\
\text { wortel, ubi jalar }\end{array}$ & $\begin{array}{l}\text { Worttel, kacang } \\
\text { tanah dan ubi } \\
\text { jalar }\end{array}$ & sesuai \\
\hline 6 & $\begin{array}{l}\text { Cukup } \\
\text { baik }\end{array}$ & Cukup baik & Cukup & Cukup & Cukup & $\begin{array}{l}\text { Kacang tanah, } \\
\text { wortel, singkong }\end{array}$ & $\begin{array}{l}\text { Wortel, cabe dan } \\
\text { singkong }\end{array}$ & sesuai \\
\hline 7 & $\begin{array}{l}\text { Cukup } \\
\text { baik }\end{array}$ & Cukup baik & Cukup & Cukup & Cukup & $\begin{array}{l}\text { Cabe,jagung,wor } \\
\text { tel }\end{array}$ & $\begin{array}{l}\text { Wortel, cabe dan } \\
\text { ubi jalar }\end{array}$ & Sesuai \\
\hline 8 & Cukup & Cukup baik & Cukup baik & Cukup baik & Cukup baik & $\begin{array}{l}\text { Jagung, ubijalar, } \\
\text { kacang ijo }\end{array}$ & $\begin{array}{l}\text { Jagung, wortel } \\
\text { dan cabe }\end{array}$ & $\begin{array}{l}\text { Tidak } \\
\text { sesui } \\
\end{array}$ \\
\hline 9 & Cukup & Cukup baik & Cukup baik & Cukup baik & Cukup baik & $\begin{array}{l}\text { Jagung, kacang } \\
\text { tanah, ubi jalar }\end{array}$ & $\begin{array}{l}\text { Cabe, ubi jalar } \\
\text { dan kacang tanah }\end{array}$ & sesuai \\
\hline 10 & $\begin{array}{c}\text { Sangat } \\
\text { baik }\end{array}$ & Sangat baik & Cukup baik & Cukup baik & Cukup baik & $\begin{array}{l}\text { Jagung, kedelai, } \\
\text { kacang tanah }\end{array}$ & $\begin{array}{l}\text { Cabe, ubijalar, } \\
\text { dan kacang tanah }\end{array}$ & $\begin{array}{c}\text { Tidak } \\
\text { sesuai }\end{array}$ \\
\hline 11 & $\begin{array}{c}\text { Kurang } \\
\text { baik }\end{array}$ & Cukup baik & Kurang baik & Sangat baik & Sangat baik & $\begin{array}{l}\text { Kacang } \\
\text { tanah,cabe } \\
\text { jagung }\end{array}$ & $\begin{array}{l}\text { cabe, jagung dan } \\
\text { ubi jalar }\end{array}$ & Sesuai \\
\hline 12 & $\begin{array}{l}\text { Tidak } \\
\text { baik }\end{array}$ & baik & Sangat baik & Cukup baik & Sangat baik & $\begin{array}{l}\text { Kacang tanah, } \\
\text { kacang hijau, } \\
\text { cabe }\end{array}$ & $\begin{array}{l}\text { Cabe, ubi jalar } \\
\text { dan jagung }\end{array}$ & $\begin{array}{l}\text { Tidak } \\
\text { sesuai }\end{array}$ \\
\hline
\end{tabular}




\begin{tabular}{ccccccccc}
\hline 13 & baik & Cukup & Cukup baik & Cukup & Cukup & $\begin{array}{l}\text { Cabe, ubijalar, } \\
\text { jagung }\end{array}$ & $\begin{array}{l}\text { Cabe, ubi jalar } \\
\text { dan jagung }\end{array}$ \\
\hline 14 & Cukup & Sangat baik & Cukup baik & baik & baik & $\begin{array}{l}\text { Ubi jalar, cabe, } \\
\text { padi }\end{array}$ & $\begin{array}{l}\text { Padi, ubi jalar } \\
\text { dan cabe }\end{array}$ & Sesuai \\
\hline 15 & $\begin{array}{c}\text { Sangat } \\
\text { baik }\end{array}$ & Sangat baik & baik & Cukup baik & baik & $\begin{array}{l}\text { Jagung, kentag, } \\
\text { cabe }\end{array}$ & $\begin{array}{l}\text { Padi, ubi jalar } \\
\text { dan cabe }\end{array}$ & $\begin{array}{c}\text { Tidak } \\
\text { sesuai }\end{array}$ \\
\hline 16 & baik & baik & baik & Sangat baik & baik & $\begin{array}{l}\text { padi, ubi jalar, } \\
\text { kacang ijo }\end{array}$ & $\begin{array}{l}\text { Jagung, ubi jalar } \\
\text { dan padi }\end{array}$ & Sesuai \\
\hline 17 & $\begin{array}{c}\text { Sangat } \\
\text { baik }\end{array}$ & Sangat baik & Sangat baik & baik & Cukup baik & $\begin{array}{l}\text { Kacang tanah, } \\
\text { ubi kayu, padi }\end{array}$ & $\begin{array}{l}\text { Ubi jalar, padi } \\
\text { dan cabe }\end{array}$ & $\begin{array}{c}\text { Tidak } \\
\text { sesuai }\end{array}$ \\
\hline 18 & $\begin{array}{c}\text { Tidak } \\
\text { baik }\end{array}$ & Cukup baik & Cukup baik & Tidak baik & Cukup & $\begin{array}{l}\text { Jagung, kacang } \\
\text { tanah, wortel }\end{array}$ & $\begin{array}{l}\text { Jagung, wortel } \\
\text { dan kedelai }\end{array}$ & Sesuai \\
\hline 19 & $\begin{array}{c}\text { Sangat } \\
\text { baik }\end{array}$ & Sangat baik & Sangat baik & Sangat baik & Cukup baik & $\begin{array}{l}\text { Cabe, padi, ubi } \\
\text { jalar }\end{array}$ & $\begin{array}{l}\text { Ubi jalar, padi } \\
\text { dan cabe }\end{array}$ & Sesuai \\
\hline 20 & $\begin{array}{c}\text { Cukup } \\
\text { baik }\end{array}$ & Cukup baik & Sangat baik & Sangat baik & baik & $\begin{array}{l}\text { Kacang tanah, } \\
\text { jagung, kedelai }\end{array}$ & $\begin{array}{l}\text { Ubi jalar, padi } \\
\text { dan cabe }\end{array}$ & $\begin{array}{l}\text { Tidak } \\
\text { sesuai }\end{array}$ \\
\hline
\end{tabular}

\section{PENUTUP}

Telah berhasil membangun system rekomen dasi tanaman pangan dengan menggunakan metode SAW berbasis website guna di implementasi kan di wilayah kabupaten Malang dan Sistem ini telah mampu menghasil kan system rekomendasi tanaman pangan yang dapat di gunakan untuk membantu petani dalam mencari tanaman yang layak untuk di tanam di wilayah Kabupaten Malang. Saran untuk penelitian yang dapat di gunakan sebagai pengem bangan selanjut nya adalah : 1). Agar system rekomendasi tanaman pangan ini lebih sempurna, maka di perlukan pengem bangan lebih lanjut terutama dengan kriteria - kriteria yang lain dan lebih lengkap. 2). Agar system rekomen dasi tanaman pangan ini mudah di gunakan di manasaja, di perlukan pengem bangan kedalam bentuk aplikasi mobile dengan harapan bias di gunakan di manapun dan kapan pun secara realtime.

\section{DAFTAR PUSTAKA}

Ahsan M, Setiyaningsih W, Susilowati S, Dijaya R, Tjahjanti PH., 2019. Selecting multiple intelligences on children with weighted product, analytical hierarchy process, simple additive weighting and TOPSIS. Journal of Physics: Conference Series Tebitan ke 7 Jilid 1402, Halaman 077033, Tahun 2019. Penerbit IOP Publishing.

Ahsan M, N Indawati,. 2019. Implementation weighted product method to determine multiple intelligence child. Journal of Physics: Conference Series Tebitan ke 1 Jilid 1375, Halaman 012038, Tahun 2019. Penerbit IOP Publishing.

Ahsan, budi P, Harry S.P., 2015. Multiple Intelligence Menentukan Jurusan di SMA Menggunakan Teknik Multi-Attribute Decision Making. Jurnal eeccis UB, Volume 9 tahun 2015.

Ariyanto, (2012), Sistem Pendukung Keputusan Pemilihan Karyawan Terbaik Dengan Metode SAW (Simple Additive Weighting), Skripsi Fakultas Sains dan Teknologi UIN SunanKalijaga, Yogyakarta.

Edi, Doro; Betshani, Stevalin, (2014), Analisis Data denganMengguna kan ERD dan Model Konsep tual Data Warehouse, Jurnal Informatika, Vol .5, No. 1, hal $71-85$.

Fiati, Rina (2015), Aplikasi Sistem Pendukung Keputusan Peramalan Penjualan Barang, ISSN : $1979-6870$ 
Joko Usito, Nugroho, (2013), Sistem Pendukung Keputusan Penilaian Proses Belajar Mengajar Menggunakan Metode Simple Additive Weighting (SAW), Tesis Program Studi Magister Sistem Informasi Universitas Diponegoro, Semarang.

Kadir, Abdul, (2005), Dasar Pemrograman JAVA TM 2 , Andi Offset, Yogyakarta.

Kusuma dewi, Sri ; Hartati , Sri ; Harjoko, Agus ; Wardoyo, Retantyo, (2006), Fuzzy Multi -Attribute Decision Making (Fuzzy MADM), Grahallmu, Yogyakarta.

Lad jamudin, bin Al-Bahra, ( 2005 ), Analisis dan Desain Sistem Informasi, GrahaI lmu, Yogyakarta.

Nugroho, Bunafit, ( 2005 ), Database Relasional dengan MySQL, Andi Offset, Yogyakarta

Okta putra , Ali Wahyu ; Noer sasongko, Edi , (2014), Sistem Pendukung Keputusan Kelayakan Pemberian Kredit Motor Menggunakan Metode Simple Additive Weighting Pada Perusahaan Leasing HD Finance, Tugas Akhir Fakultas Ilmu Komputer Universitas Dian Nuswantoro, Semarang.

Supriyanto , Aji , (2007), Pengantar Teknologi Informasi, Salemba Infotek, Jakarta. 